In any event, it seems that the multiplicity of hormone production in oat-cell tissue tumours is not exhausted with the combinations so far presented.

The detailed description of this case is to be published in the Acta Medica Academiae Scientiarum Hungarica.-We are, etc.,

L. MosonYI G. SzILÁGYI E. SZATLóczky L. GRÁF

E. Palásthy

IVth Department of Medicine, Postgraduate Medical School, Budapest XII

1 Liddle, G. W., Givens, J. R., Nicholson, W. E., and Island, D. P., Cancer Research, 1965, 25, 105

Sommers, Sh. C., in Endocrine Pathology, ed. and Wilkins, 1968.

Davis, B. J., Annals of the Nero York Academy of Smith A. N., et al., Scottish Medical fournal,
1957, 2, 24.

\section{Hypoglycaemia in Infancy and Childhood}

SIR,-It was with great relief that I read the leading article on "Hypoglycaemia in Infancy and Childhood" (17 July, p. 130). At last there is guidance on the "controversial" point of whether or not to treat asymptomatic hypoglycaemic infants. These infants warrant intravenous therapy until there is evidence to the contrary.

Can we now expect that requests for true glucose levels on neonates "at risk" will be recognized as urgent and necesary investigations by pathology departments throughout the country?

It may well be that these actions will help to reduce the number of school children with learning difficulties in the future. -I am, etc.,

London S.W.12

Norman Peter Halliday

\section{Cerebral Vasodilators}

STR.-I am writing to support Dr. C. G. Elliott's comments (17 July, p. 185) on your article on cerebral vasodilators in Today's Drugs (19 June, p. 702).

I entirely agree with Dr. Elliott that your article echoes the currently orthodox and rather nihilistic views on the treatment of cerebral arteriosclerosis, and that this is probably because the diagnosis of the condition is made at too advanced a stage rather than necessarily being due to the inefficacy of vasodilator drugs.

Dr. Mary Harcup and $\mathbf{P}$ found in a detailed clinical study of a number of these patients that visual inspection of the electroencephalogram provided little in the way of early diagnostic features and, obviously, once clinical symptoms have appeared, these tend to be irreversible because of the absence of neuronal regeneration. It therefore seems highly desirable that some way of making the diagnosis before neurological signs appear is discovered, and we have currently completed a further study of these patients which we hope to publish in the near future, this time using a quantitative computer-linked analysis of the electroencephalogram by automated low frequency wave analysis as well as detailed clinical scales. This study has involved assessment of cyclandelate (one of the cerebral vasodilators mentioned) under strictly controlled conditions. This drug has already been found to be effective in improving mental function and cerebral blood flow under controlled conditions $^{2}$ and a recent symposium on its use $^{3}$ confirms the high probability of its effectiveness. Cyclandelate has been found objectively to increase cerebral blood flow, reduce arterial spasm, and to improve to a clinically very relevant degree many of these symptoms of cerebral arteriosclerosis.

It is, as Dr. Elliott remarks, extraordinary that its safety and apparently real, if perhaps modest, success in a common and extremely distressing and crippling malady has not caused more enthusiasm among some sections of the profession.-I am, etc.,

Powick Hospital, Worcs

Peter HaI

1 Hall, P., and Harcup, M., Angiology, 1969, 20, 2 Ball, J. A. C., and Taylor, A. R., British Medical Fournal, 1967, 3, 525 . Assessment in Cerebrovascular Insufficiency, ed.
R. A. Kuhn, et al., Thieme, Stuttgart, 1970.

\section{Epilepsy and Driving}

SIR,-I have read with interest the article on epilepsy and driving by Drs. R. D. H. Maxwell and G. E. Leyshon (3 July, p. 12). I must confess, however, that I have found their presentation of facts and figures somewhat difficult to follow and I have misgivings about some of their conclusions.

In particular, I find it hard to accept their assumption that "many and probably most epileptics have obtained driving licences by concealment of their condition." Assuming that there are annually 440 people with epilepsy in the West Riding licensing authority area who could apply for driving licences, do we really know what proportion of such people actually do so? The supposition that some 9 out of 10 male subjects with epilepsy may have concealed their disability in violation of the Road Traffic Act of 1961 does not therefore seem to me to have been very clearly established.

However, even if the authors' assumption were a valid one, it does not follow that relaxation of the regulations for the granting of a driving licence will lead to a perpetuation of such a state of affairs. Presumably it is more likely to operate in the opposite derection, but further facts and figures will be needed to establish whether or not this turns out to be the case.

With regard to the E.E.G. criteria as applied to the 855 patients in the authors' group 2, I cannot comment usefully upon them because these have not been defined in detail. I would however like to emphasize that in my experience there have only been rare occasions when the E.E.G. findings played a decisive role in the assessment of fitness to drive so far as the history of epilepsy was concerned. The utmost caution must at all times be exercised in assessing their clinical significance, and I have seen most unfortunate results accrue when this basic rule has not apparently been observed.

In my opinion the authors are right to stress the importance of patients' testimony, and the importance of obtaining corroborative evidence whenever possible cannot be over-emphasized. There is certainly some- thing to be said for the provision of a certificate of fitness by people with past histories of epilepsy who wish to hold driving licences.-I am, etc.,

MaUrice Parsonage Chairman, Medical Committee of the British Epilepsy Association

Neurological Department,

Leeds General Infirmary,

Leeds, Yorks

\section{Morbidity after Dental Anaesthesia}

SIR,-The Society for the Advancement of Anaesthesia in Dentistry is sponsoring a survey to inquire into all known cases of morbidity after dental anaesthesia.

I shall be grateful if readers can inform me of any cases of which they have personal knowledge, or of authorities to whom my subcommittee can refer for further information of such cases.-I am, etc.,

M. W. P. HudsoN Chairman, Subcommittee on Postgraduate Education, Society for the Advancement of Anaesthesia
in Dentistry

53 Wimpole Street,
London W.1

\section{The Community Paediatrician}

SIR,-I hope others feel as grateful as I do to Professor Ross G. Mitchell for his clear and convincing analysis of the need for, and the training of, the community paediatrician of the future (10 July, p. 95). But I have to take issue with two articles of his faith.

He asserts that "The present-day doctor ... approaches a problem .... with little real appreciation of the interplay of physical, emotional, and social factors which have created the difficulty." I must challenge the truth of this in respect of most general practitioners; they, par excellence, are aware of the said interplay (especially if welltrained health visitors are attached to the practice) and do an amateur's best to help the patient to achieve adjustment. I certainly hope that the gradual introduction of behavioural science into undergraduate and postgraduate medical education will help to improve the professionalism of all doctors in the wider aspects of patient care. Equally, I hope that too much will not be expected too quickly of the behavioural sciences and that meantime the value of experience in general practice will not be undervalued.

Professor Mitchell gives us a glimpse of the imaginative programme of training already under way in Aberdeen. But surely it omits one essential for the future community paediatrician? A period in general practice, even if it were no more than three months (the present trainee general practitioner scheme could be adapted to make this feasible), would give the trainee paediatrician some experience of the common illnesses of childhood, both physical and psychological, some insight into the interplay of personalities that can both cause and help to cure the problems, and a better understanding of the difficulties the general practitioner and his team have to face. Of course such a short exposure to general practice is far from ideal, but where a loaf cannot be had, a slice is better than nothing.

Just as vocational training for general practice looks to the paediatrician for help, so must the medical specialist acknowledge 